\title{
Migraine and Galcitonin Gene-Related Peptide Receptor Antagonist Treatment
}

\author{
Yasemin Akbaş (1)
}

\section{MIGRAINE}

Migraine is a nerve and vascular disease characterized by throbbing and severe headache, often unilateral. Attacks are usually associated with nausea, vomiting or light, sound, sensitivity to movement. ${ }^{[1]}$ Primary headaches are headaches that are not associated with the central nervous system and other systemic diseases. Migraine falls into primary headache class according to the ICHD-3 classification of the International Headache Society. Chronic migraine is defined as headache for more than 15 days per month, with at least 8 days of migraine; migraine is defined as headache lasting more than 72 hours. ${ }^{[2]}$

About $15 \%$ of the world's population has migraine. It affects $12 \%$ of adults, $18 \%$ of women, and $6 \%$ of men in Western countries. With the negative impact on the patient's quality of life, it causes a tremendous socioeconomic burden on society. Although not all stages are seen in each patient, there are four different stages according to clinical characteristics: early warning, migraine aura, headache phase and postattack phase. One-third of the patients experience a migraine attack called "aura" before the onset of

Istanbul Aydın University Medical School, Istanbul, Turkey

Correspondence: Yasemin Akbaş. İstanbul Aydın Üniversitesi Tıp Fakültesi, 34295 Sefaköy, Küçükçekmece, İstanbul, Türkiye.

E-mail: yaseminakbas.ya@gmail.com

Cite this article as: Akbaş Y Migraine and Calcitonin Gene-Dependent Peptide Receptor Antagonist Treatment. JEB Med Sci 2020;1(2):79-81.

doi: $10.5606 /$ jebms.2020.75617

Received : August 15, 2019

Accepted : August 20, 2020

Published online : November 09, 2020

๑ 2020 Journal of Experimental and Basic Medical Sciences. All rights reserved.

\begin{abstract}
Migraine is one of the primary causes of headache that reduces people's quality of life and work force, mostly affecting young and middle-aged individuals. Although many treatment options have been put forward, the treatment is still not satisfactory for many patients today. CRGP is a peptide neurotransmitter produced in numerous regions in the central nervous system. It takes part in communication between nerve cells and enables the vessels to expand, especially in areas where the need for blood increases in the brain. This vein expander triggers headaches in migraine patients, causing the body to react abnormally. Because CGRP is an important molecule for the brain to function in its normal order, there has been success in treatments done by shutting down its receptors rather than completely neutralizing them in the body. Selective CGRP receptor antagonists should be effective antimigrene drugs. Keywords: Antimigraine drug, calcitonin gene-dependent peptide, headache, migraine, receptor antagonists, treatment.
\end{abstract}

migraine headaches, such as flashing light and bad smells in the visual field. ${ }^{[3]}$

In migraine headaches with or without aura, first activation and then sensitization of the trigeminal and upper cervical nerves occur, giving the migraine headache a characteristic throbbing. Migraine without aura in women is also associated with menstruation. Menstruation is a triggering factor. $80-85 \%$ of migraine headaches are migraine without aura and $15-20 \%$ are migraine with aura. ${ }^{[2]}$

\section{Pathophysiology of Migraine}

With the information obtained in recent years, neurovascular theory has been adopted instead of vascular theory in the pathophysiology of migraine. Vascular theory suggests that migraine symptoms occur with vasodilation in the skull whereas neurovascular theory suggests that vascular changes are seen secondary to neuronal activation in migraine headaches. As a result of 
neural events, blood vessels in pain-sensitive structures expand and cause trigeminal nerve activation and pain. ${ }^{[4]}$ PET and functional MRI studies have shown that brainstem is activated during migraine attacks. ${ }^{[5]}$ Current hypotheses associate primary dysfunction with brainstem centers that regulate vascular tension and sense of pain. The blood vessels and cerebrospinal membranes in the skull, particularly pain-sensitive structures such as the dura mater, are fed by the ophthalmic branch of the first branch of the trigeminal nerve with sensory nerve fibers. A signal is transmitted from neurons in the trigeminal nucleus of the brain stem resulting in pain experience. ${ }^{[6]}$

\section{Peptide and Calcitonin Gene-Related Peptide (CGRP) Receptors Associated With the Calcitonin Gene}

Calcitonin gene-related peptide is a neurotransmitter consisting of 37 amino acids produced in numerous sites along peripheral sensory neurons and throughout the central nervous system. It was first described in 1983 in rats. ${ }^{[3,7]}$ Electrical stimulation of the trigeminal ganglion in both humans and cats results in an increase in blood flow outside the brain and release of both the CGRP and substance $P^{[8]}$ The release of neuropeptides such as CGRP, substance $P$, into the peripheral vascular site leads to vasodilation, increased blood flow, and neurogenic inflammation This vascular dilation and edema lead to more stimulation of the perivascular trigeminal axons and more pain. ${ }^{[4]}$

All CGRP-targeted therapies tested for migraine treatment to date have produced positive results. ${ }^{[9]}$ CGRP receptor antagonists provide relief in an acute headache attack, with or without aura. Monoclonal antibodies to CGRP or its receptor are effective for preventing occasional or chronic migraine. ${ }^{[7]}$

Studies on the peptide receptor antagonists olcegepant and telcagepant associated with the calcitonin gene emerged at the beginning of the $21^{\text {st }}$ century. Information from animal studies has shown that olcegepant can suppress the stimulating effects of CGRP on intact blood vessels. However, it has been found that injecting olcegepant intravenously into healthy volunteers does not cause significant systemic or blood flow changes in the brain. ${ }^{[10]}$

Findings from pharmacological studies have shown that telcagepant is a highly potent antagonist of the CGRP receptor, thus having a good efficacy in the treatment of migraine. ${ }^{[1]}$ Despite positive clinical data supporting the use of telcagepant in the acute treatment of migraine, significant increases in liver enzymes were observed in patients receiving telcapant twice daily for three months. ${ }^{[11]}$ Triptans, another class of drugs used in the treatment of migraine, inhibit presynaptic serotonin receptors CGRP release. These receptors are targets of triptans. However, some patients experience side effects such as dizziness and cardiovascular disease. ${ }^{[12]}$

In conclusion, peptide receptor antagonists associated with the calcitonin gene are effective and well tolerated therapies; however, long-term highdose medication may lead to impaired liver function in some patients, requiring further investigation. ${ }^{[13]}$

\section{Declaration of conflicting interests}

The author declared no conflicts of interest with respect to the authorship and/or publication of this article.

\section{Funding}

The author received no financial support for the research and/or authorship of this article.

\section{REFERENCES}

1. Goadsby PJ, Lipton RB, Ferrari MD. Migraine-current understanding and treatment. $N$ Engl J Med 2002;346:257-70.

2. Bıçıkçı Ş, Öztürk $M$, Üçler $S$, Karlı N, Siva $A$, editörler. Başağrısı Tanı ve Tedavi Güncel Yaklaşımlar. İstanbul: Galenos Yayınevi; 2018.

3. Villalon CM, Olesen J. The role of CGRP in the pathophysiology of migraine and efficacy of CGRP receptor antagonists as acute antimigraine drugs. Pharmacology \& Therapeutics 2009;124:309-23.

4. Bolay H, Dalkara T. Birincil baş ağrılarının fizyopatolojisi. Türkiye Klin Dahili Tıp Bilim Nöroloji Derg Başağrısı Özel Sayısı 2003;1:98-102

5. Boran HE, Bolay H. Pathophysiology of Migraine. Noro Psikiyatr Ars 2013;50(Suppl 1):S1-S7.

6. Goadsby PJ. Recent advances in understanding migraine mechanisms, molecules and therapeutics. Trends Mol Med 2007;13:39-44.

7. Edvinsson L, Haanes KA, Warfvinge K, Krause DN. CGRP as the target of new migraine therapies - successful translation from bench to clinic. Nat Rev Neurol 2018;14:338-50.

8. Goadsby PJ, Edvinsson L, Ekman R. Release of vasoactive peptides in the extracerebral circulation of humans and the cat during activation of the trigeminovascular system. Ann Neurol 1988;23:193-6.

9. Schuster NM, Rapoport AM. Calcitonin GeneRelated Peptide-Targeted Therapies for Migraine and Cluster Headache: A Review. Clin Neuropharmacol 2017;40:169-74.

10. Fischer MJ, Koulchitsky S, Messlinger K. The nonpeptide calcitonin gene-related peptide receptor antagonist BIBN4096BS lowers the activity of neurons with 
meningeal input in the rat spinal trigeminal nucleus. J Neurosci 2005;25:5877-83.

11. Moore EL, Burgey CS, Paone DV, Shaw AW, Tang YS, Kane SA, et al. Examining the binding properties of MK-0974: a CGRP receptor antagonist for the acute treatment of migraine. Eur J Pharmacol 2009;602:250-4.
12. Yao G, Yu T, Han X, Mao X, Li B. Therapeutic effects and safety of olcegepant and telcagepant for migraine: $A$ meta-analysis. Neural Regen Res 2013;8:938-47.

13. Durham PL, Vause CV. Calcitonin gene-related peptide (CGRP) receptor antagonists in the treatment of migraine. CNS Drugs 2010;24:539-48. 